\title{
Leuzea repens, a new combination (Compositae: Cardueae: Centaureinae)
}

\section{J. Nicholas Hind ${ }^{1}$}

Summary. The taxonomic concepts and nomenclatural issues surrounding a group of taxa, often placed into 'Rhaponticum Vaill.' sensu auct. mult., are discussed. Taxonomically, taxa belonging to Acroptilon, Leuzea, Stemmacantha and 'Rhaponticum Vaill.', are now considered congeneric. 'Rhaponticum Vaill.' is not considered a validly published generic name and taxa are now recognised under the generic name Leuzea, which has priority. The taxonomic position of Acroptilon repens (Compositae: Cardueae: Centaureinae), the only representative of the genus in Iraq, has been reviewed and a new combination in Leuzea is provided, together with an exhaustive synonymy of the taxon concerned.

Key Words. Asteraceae, Chewing Disease, Flora of Iraq.

\section{Introduction}

During the initial editing of the draft Flora of Iraq Compositae account, written by several authors some 35 or more years ago, the present author was faced with updating much taxonomy and sorting out many nomenclatural issues with the various scripts. One of these concerned Francis Davies's original draft account of the genus Acroptilon Cass. (Compositae: Cardueae: Centaureinae), and the sole species in the Flora, A. repens (L.) DC.

Acroptilon repens is a widely distributed taxon, and a noxious weed, possibly best known as the Russian knapweed (Maddox et al. 1985; Moore 1972; Quattrocchi 2000: 38; USDA 2015; also known as creeping knapweed, hardheads, and Turkestan thistle - Klein 2011). Its toxicity is reported as causing Chewing Disease (nigropallidal encephalomalacia), a neurological disorder in horses, a response also seen to be caused by Centaurea solstitialis L. in the same subtribe (Anon 2015; Vetstream 2014).

It became apparent to the present author that the generic placement of Acroptilon was questionable, and brought with it nomenclatural implications. Further study indicated that Acroptilon repens belonged to what Susanna \& Garcia-Jacas (2006) had termed the 'III.5.B. Rhaponticum Group', that in turn formed part of the subtribe Centaureinae. This group, of perhaps some 40 species, included the genera Acroptilon, Leuzea DC., 'Rhaponticum Vaill.' and Stemmacantha Cass. (Susanna \& Garcia-Jacas 2006: 142 - 144; Hidalgo et al. 2006). Earlier, in his treatment of the subtribe Centaureinae, Bremer (1994: 149 - 156) recognised a monospecific Acroptilon (A. repens) and Stemmacantha (containing about 20 species); 'Rhaponticum Hill' was placed into the synonymy of the latter; two literature references were provided, the first to Holub (1973) and, the second, to Dittrich (1984).

Holub (1973) had long-recognised that within the Centaureinae there were taxonomic issues with both Rhaponticum sensu auct. and Leuzea, and that the work of Soskov (1959) and Dittrich (1968a, b) had scarcely resolved them, together with the clear nomenclatural issues that still existed. Holub concluded that Leuzea (based on L. conifera (L.) DC.) was congeneric with Cestrinus Cass., Stemmacantha, Fornicium Cass. and Malacophyllum Tausch along with several species belonging to Rhaponticum sensu auct., synonymising all, reducing the genera to subgenera of Leuzea and providing many new combinations. In his discussions on the nomenclature, he highlighted and summarised the many issues with the generic name Rhaponticum, concluding that it should only be ascribed to Ludwig, and now considered synonymous with Centaurea L.; the present author concurs with this view. Holub did not treat Acroptilon repens within his 'Contribution', mentioning only the common basic chromosome number of $x=13$ amongst several genera within the Centaureinae, including Acroptilon.

The taxonomy of Holub's and Dittrich's (Dittrich 1968a, 1975, 1984) concepts of this group of species was subjected to analysis (of one plastid and two nuclear marker/s) in an attempt to resolve the delimitation of the 'Rhaponticum group' (Hidalgo et al. 2006). Hidalgo et al. provided a 'DNA phylogeny of Rhaponticum and related genera' from which a quite reasonable taxonomic resolution was presented. The 'Rhaponticum group' was clearly comprised of the concepts of Acroptilon, Leuzea and 'Rhaponticum Vaill.'

\footnotetext{
Accepted for publication 8 April 2019. Published online 18 May 2019

1 Herbarium, Royal Botanic Gardens, Kew, Richmond, Surrey, TW9 3AE, UK. e-mail: n.hind@kew.org
} 
(三 Stemmacantha) and usefully divided into two clades that Hidalgo et al. informally recognised as the 'Oriental clade' and the 'Occidental clade'; it was in the former that $A$. repens (and A. australe Iljin) was placed. Furthermore, since the authors could not entirely resolve the relationship between $A$. repens and $A$. australe they merely provided a new combination of the former under Rhaponticum. The implications surrounding A. australe are discussed below.

Ascription of the authorship of Rhaponticum to Vaillant (e.g. Greuter 2003; Greuter et al. 2005; Zhu \& Martins 2011) fails to recognise the issue with Vaillant's many names (see Brummitt 2008; Greuter 2008; Greuter \& McNeill 2008; Hind et al. 2007; Susanna 2009). This can be summarised by essentially discounting a post-Linnaean translation (i.e. post-1753 — 'Vaillant' 1754) (of a pre-Linnaean work of Vaillant, dating from 1719) that many authors considered provided validation of Vaillant's names. Holub (1973) had correctly recognised that Leuzea had priority and made many of the required combinations - apart from considering A. repens. Since Hidalgo et al. (2006: 709, 711) clearly placed Acroptilon within the concept of Rhaponticum, here recognised as Leuzea, a new combination is required This is provided below.

\section{New combination}

Following the new combination, a fairly exhaustive synonymy of the taxon is provided. After the citation of each name and its place of publication, the 'type citation' in a traditional sense is provided (as a direct quote from the protologue, regardless of whether a specimen was cited). The location of type material is cited, where known and, when available, the barcode numbers present with the material given. Many of the digital images of the 'types' can be seen through JStor Global Plants (JSTOR-GP continuously updated), institutional subscriptions permitting.

\section{Leuzea repens (L.) D.J.N.Hind, comb. nov.}

http:/ /www.ipni.org/urn:lsid:ipni.org:names:60478474-2

Centaurea repens L., Sp. Pl., ed. 2. 2: 1293 (Linnaeus 1763). Type: 'Habitat in oriente.', LINN-LH 1030.34 .

Centaurea picris Pall. ex Willd. (Willdenow 1803: 2302). Type: 'Habitat ad mare Caspium. (v. s.)'. Type material: B-W(16601-01 0, 16601-02 0, 16601-03 0), $\mathrm{BM}(000996201)$. Note: Of the material in B-W none indicate the locality - B-W(16601-01 0$)$ is marked 'C. Picris 1.' on the top right hand corner of the sheet, and was most probably determined by Marschall von Bieberstein as 'Serratula picris MB' on a label to the lower left of the specimen, and subsequently redetermined as Rhaponticum repens (L.) Hidalgo by Martins (Mai 2009); B-W(16601-02 0 ) is marked ' $C$. Picris 2' on the top right hand corner of the sheet, and has a small label at the bottom of the sheet — 'Cent. Picris Pall./(W.)' The sheet bears an annotation label by Cronquist (1989) suggesting this is 'presumably the type of Centaurea picris Pallas ex Will. = C. repens L.'. On neither the first or second sheets are there any lower leaves with anything but entire basal margins. The third sheet, B-W(16601-03 0), is annotated 'C. Picris 3' on the top right hand corner of the sheet. It is labelled as 'Centaurea pycris Pall./(Adams)'. This sheet bears some lower leaves that are 'subdentatis', as indicated in the protologue, but the leaves in general are much narrower than on the other two sheets. The material from BM is clearly ex Herb. Pallas, with the top left hand label indicating the locality as 'Caspica', and it is quite clear that the basal margins of many leaves are 'subdentatis', although more frequently conspicuously toothed to lobed. Since the Pallas herbarium was sold in 1808, and part purchased by Lambert and deposited in BM (Miller 1970 - Pallas material was discussed at length and was sold in the auction of Lambert's herbarium in three lots, \#94, \#96 and \#285.), it is highly probable that Willdenow had seen the material in Pallas's herbarium in preparing his Species Plantarum (Willdenow 1803); the BM material should therefore not be discounted if lectotypification of the name is considered necessary.

Serratula picris (Pall. ex Willd.) M.Bieb. (Marschall von Bieberstein Dec. 1819 or early 1820: 546).

Acroptilon obtusifolium Cass. (Cassini 1827: 465). Type: 'Nous avons fait cette description sur un échantillon sec de l'herbier de M. Desfontaines, étiqueté Centaurea picris, ...' Holotype: ?P or FI.

Acroptilon subdentatum Cass. (Cassini 1827: 465). Type: see citation for A. serratum. Holotype: ?P.

Acroptilon serratum Cass. (Cassini 1827: 466). Type: 'Nous avos décrit cette espèce et la précédente [=Acroptilon subdentatum $]$ sur des échantillons secs, innommés, dont nous ignorons l'origine.' Holotype: ?P.

Acroptilon angustifolium Cass. (Cassini 1827: 466). Type: 'Nous avons faite cette description sur un échantillon sec qui appartient problement à la Centaurea repens de Linné.' Holotype: ?P.

Carduus picris (Pall. ex Willd.) Sweet (1830: 281).

Acroptilon picris (Pall. ex Willd.) C.A.Mey. (Meyer 1831: 67).

Acroptilon picris (Pall. ex Willd.) DC. (de Candolle 1838: 662), comb. superfl.

Acroptilon picris (Pall. ex Willd.) C.A.Mey. var. $\alpha$ obtusifolia (Cass.) DC. (de Candolle 1838: 662).

Acroptilon picris (Pall. ex Willd.) C.A.Mey. var. $\beta$ angustifolia (Cass.) DC. (de Candolle 1838: 662). 
Acroptilon picris (Pall. ex Willd.) C.A.Mey. var. $\gamma$ subdentata (Cass.) DC. (de Candolle 1838: 662).

Acroptilon picris (Pall. ex Willd.) C.A.Mey. var. $\delta$ oxylepis DC. (de Candolle 1838: 662). Type: [Iran:] 'ad agrorum margines circà Seidchadschi prov. Aderbeischan Persiae legit cl. Szowitz. Acr. Picris var. Fisch. et Mey.! pl. Szow. ined. (v. s.)' Holotype: G-DC,(G-00486874).

Acroptilon picris (Pall. ex Willd.) C.A.Mey. var. $\varepsilon$ serrata (Cass.) DC. (de Candolle 1838: 663).

Acroptilon repens (L.) DC. (de Candolle 1838: 663).

Acroptilon australe Iljin (1937: 59). Type: 'Turcomania, Kisil-Imam ad fl. Czan-dar, 12 VI 1912 n. 3919, leg. V. Lipsky et A. Michelson (Herb. Inst. Bot. Ac .Sc. URSS).' Holotype: LE.

Acroptilon repens (L.) DC. f. sphaerica Bornm. (Bornmüller 1940: 209), nom. inval. — see Discussion. [Based on: 'Iter Persico-turcicum 1892-93. No 4069. Persiae austro-orient. prov. Kerman: Kerman, in cultis. 1900 m. s. m. 1892. V. 13. legit et determ.: J. Bornmüller.' Original material: JE(00015673).]

Acroptilon repens (L.) DC. f. cylindrica Bornm. (Bornmüller 1940: 209), nom. inval. — see Discussion. [Based on: 'Iter Persico-turcicum 1892-93. No. 4067. Persiae austro-orient. prov. Kerman: Kerman, m. Kuhtagh-Ali. 2100 m. s. m. 1892. V. 10. legit et determ.: J. Bornmüller.' Original material: JE(00015672).]

Acroptilon repens (L.) DC. f. macrocephala Bornm. (Bornmüller 1940: 209), nom. inval. — see Discussion. [Based on: '[Iran:] Iter Persico-turcicum 189293. No. 4066. Persiae austro-orient. prov. Kerman: Kerman, ad Dschupar. 2000 m. s. m. 1892. VI. 8. legit et determ. J. Bornmüller.' Original material: $\mathrm{JE}(00015678)$.]

Acroptilon repens (L.) DC. f. macrolepis Bornm. (Bornmüller 1940: 209), nom. inval. — see Discussion. [Based on: Iter Persico-turcicum 1892-93. No. 4064. Persiae austro-orient. prov. Kerman: Kerman, in incultis. $1900 \mathrm{~m}$. s. m. 1892. 19. V. legit et determ.: J. Bornmüller - Original material: JE(00015677); 'Iter Persico-turcicum 1892-93. No. 4065. Persiae austro-orient. prov. Kerman: in incultis. 2000 m. s. m. 1892. V. 19. legit et determ.: J. Bornmüller. — Original material: JE(00015686).]

Acroptilon repens (L.) DC. f. tincta Bornm. (Bornmüller 1940: 209), nom. inval. — see Discussion. [Probably based on: 'am Lalesar, 300 m (11.VII.1892; [Bornmüller] no. 4071'. No original material found.] Acroptilon repens (L.) DC. subsp. australe (Iljin) Rech.f. (Rechinger 1980: 309).

Acroptilon repens (L.) DC. subsp. australe (Iljin) Gubanov (1996), isonym.

Rhaponticum repens (L.) Hidalgo (in Hidalgo et al. 2006: 714).

DISTRIBUTION. S Russia, Turkey, Iran, N Iraq, Afghanistan, Pakistan, Kashmir, C Asia (Turkmenia to Uzbek- istan), W Mongolia, China (Sinkiang), W Siberia. Introduced and widespread as a noxious weed in the USA (introduced late 19th century as an alfalfa contaminant) and Canada (Moore 1972), and now recognised as a weed in Argentina (Zuloaga \& Morrone 1999).

DISCUSSION. Bornmüller (1940: 209), as part of his considerable output on his Iter Persico-turcicum 1892 - 1893, provided a short commentary on the variation he had observed in Acroptilon repens. He mentioned several formas in this discussion, and this appears to be the earliest record of these names, even following exhaustive searches of the works by Bornmüller mentioned by Rechinger (1955). As all the diagnostic prose is in German these are not considered to be validly published as they appeared at least five years after the relevant date for the requirement of Latin diagnoses in the Code; they are thus contrary to Art. 39.1 (Turland et al. 2018). If separately published labels of Bornmüller's Iter Persicoturcicum were made available these would constitute valid publication of Bornmüller's taxa as there is invariably a short Latin phrase under Bornmüller's trinomial, the infraspecific epithet often with a penned rank added between 'Pall.' and the infraspecific name. Duplicates of the relevant Bornmüller material are widely distributed (e.g., K, P, etc.).

Although Iljin (1937) considered Acroptilon australe distinct from A. repens, as did Soskov (1959), later authors (e.g. Rechinger 1980; Gubanov 1996) considered it a variant of A. repens, as subspecies australe (Iljin) Rech.f. Hidalgo et al.'s (2006) commentary on 'The Rhaponticum oriental clade' indicated that their results precluded coming to a 'verdict' over whether the two taxa were distinct. If, however, research supports the continued recognition of a separate $A$. australe, a new name will have to be provided within Leuzea; Leuzea australis Gaudich., an Australian endemic, already exists.

\section{Acknowledgements}

The author would like to thank two anonymous reviewers for their comments.

Open Access This article is distributed under the terms of the Creative Commons Attribution 4.0 International License (http://creativecommons.org/ licenses/by/4.0/), which permits unrestricted use, distribution, and reproduction in any medium, provided you give appropriate credit to the original author(s) and the source, provide a link to the Creative Commons license, and indicate if changes were made.

\section{References}

Anon. (2015). Understanding Horse Nutrition. Understanding-Horse-Nutrition.com (Web pages viewed January 2016). 
Bornmüller, J. (1940). [Compositae.] In: Iter Persicoturcicum 1892 - 1893. Beiträge zur Flora von Persien, Babylonien, Assyrien, Arabien. (Forsetzung III). Beih. Bot. Centralbl. Abt. B, 60: 181 - 228. [Note: The journal title is often cited as 'Beih. Bot. Centrabl., Abt. 2 (e.g. in IPNI), but it is clear from the title page that in the later volumes it is 'Abteilung B. [Systematik, Pflanzengeographie, angewandte Botanik etc. Verlag C. Heinrich, Dresden.]' - and not '[Verlag] Kassell, Dresden' given in IPNI, which is the place of publication of the very early volumes of the Beihefte's Abteilung 2]

Bremer, K. (1994). Tribe Cardueae. In: Asteraceae: Cladistics E Classification, pp. 112 - 156. Timber Press, Portland, Oregon.

Brummitt, R. K. (2008). Proposal to add the 1754 1756 German translation of S. Vaillant, Établissement de nouveaux caractères de trois familles, 1719 - 1725, to the "Opera utique oppressa". Taxon 57(2): 663.

de Candolle, A. P. (1838). Prodromus systematis naturalis regni vegetabilis, sive enumeratio contracta ordinum, generum, specierumque plantarum huc usque cognitarum, juxta methodi naturalis normas digesta. Pars Sexta: Sistens Compositarum continationem. Treuttel \& Würtz, Parisiis.

Cassini, H. (1827). Acroptilon, H. Cass. In: F. Cuvier (ed.), Dictionnaire des science naturelles, ... Ed. 2, 50: 464 - 467. Levrault, Strasbourg \& Paris, Normant, Paris.

Dittrich, M. (1968a). Karpologische Untersuchungen zur Systematik von Centaurea und verwandten Gattungen. Bot. Jahrb. Syst. 88: 70 - 122123 - 162.

(1968b). Morphologiscche Untersuchungen an den Früchten der Subtribus Cardueae Centaureinae (Compositae). Willdenowia 5(1): 67 107.

(1975). Rhaponticum Hill. In: P. H. Davis (ed.), Flora of Turkey and the East Aegean Islands, Vol. 5: 460 - 461. University Press, Edinburgh.

(1984). Neukombinationen in der Gattung Stemmacantha Cass. (Compositae) mit Bemerkungen zur Typisierung einiger ihrer Arten. Candollea 39: 45 - 49.

Greuter, W. (2003). The Euro+Med treatment of Cardueae (Compositae) - generic concepts and required new names. Willdenowia 33: $49-61$.

(2008). Proposals to conserve the names Leysera against Asteropterus, Volutaria against Amberboi, Rhaponticum with a conserved type, and Rhaponticoides against Bielzia (Compositae). Taxon 57(3): 1001.

\& McNeill, J. (2008). Damn Vaillant? A reply to Brummitt in Taxon 57(3): 663. 2008, and some alternative proposals, including adding all Steinwehr's translations in Königl. Akad. Wiss. Paris Phys. Abh. 5-9. 1754-1760 to the "Opera utique oppressa”. Taxon 57(3): 1015 - 1016.
, Aghababian, M. \& Wagenitz, G. (2005). Vaillant on Compositae - systematic concepts and nomenclatural imact. Taxon 54(1): 149 - 174.

Gubanov, I. A. (1996). Konspect flory Vneschney Mongolii (Sosudistye rasteniya). Moskva. [In Russian].

Hidalgo, O., Garcia-Jacas, N., Garnatje, T. \& Susanna, A. (2006). Phylogeny of Rhaponticum (Asteraceae, Cardueae-Centaureinae) and related genera inferred from nuclear and chloroplast DNA sequence data: taxonomic and biogeographic implications. Ann. Bot. (Oxford) 97(5): $705-714$.

Hind, D. J. N., Strange, K. \& Broome, J. (2007). Plate 603. Helichrysum orientale. Compositae. Curtis's Bot. Mag. 24(4): 251 - 259.

Holub, J. (1973). Contributions to the taxonomy and nomenclature of Leuzea DC. and Rhaponticum auct. Folia Geobot. Phytotax., Praha 8(4): 377 - 395.

Iljin, М. М. (1937). НОВЫЙ РОД И НОВЫЕ ВИДЫ СЛОЖНОЦВЕТНЫХ [Genus novum et species novae Compositarum]. Bot. Mater. Gerb. Bot. Inst. Komarova Akad. Nauk S.S.S.R. [= Not. Syst. Herb. Inst. Bot. Acad. Sci. URSS (Leningrad)] 7 (3): 51 - 71. [In Latin and Russian].

JSTOR-GP (continuously updated) JSTOR Global Plants. Published on the Internet https:// plants.jstor.org/

Klein, H. (2011). Russian knapweed. Acroptilon repens (L.) de Candolle. Data sheet from Alaska Natural Heritage Program, University of Alaska Anchorage. (sourced via http:/ / aknhp.uaa.alaska.edu as a PDF).

Linnaeus, C. (1763). Species plantarum, exhibentes plantas rite cognitas, ad genera relatas, cum differentiis specificis, nominibus trivialibus, synonymis selectis, locis natalibus, secundum systema sexuale digestas. Ed. 2. Laurentii Salvii, Holmiae.

Maddox, D. M., Mayfield, A. \& Poritz, N. H. (1985). Distribution of Yellow Starthistle (Centaurea solstitialis) and Russian Knapweed (Centaurea repens). Weed Sci. 33(3): 315 - 327.

Marschall von Bieberstein, F. A. (Dec. 1819 or early 1820). Flora taurico-caucasica [exhibens stirpes phaenogamas, in Chersoneso taurica et regionibus caucasicis sponte crescentes.] Supplementum continens plantas phanerogamas, per Tauriam atque Caucasum, post edita priora volumine detectas, et in pristinas animadversiones. Vol. 3. Typis academicis, Charkouiae.

Meyer, C. A. von (1831). Verzeichniss der Pflanzen, welche während der, auf Allerhöchsten Befehl, in den Jahren 1829 und 1830 unternommenen Reise im Caucasus und in den Provinzen am westlichen Ufer des Caspichen Meeres gefunden und eingesammelt worden sind. Bericht, abgestattet an die kaiserliche Academie der Wissenschaften in St. Petersburg, in ihrer Sitzung vom 30 März (11 April) 1831 vom Dr. Carl Anton Meyer. Gedruckt in der Buchdruckerei der kaiserl. Akademie der Wissenschaften, St. Petersburg. 
Miller, H. S. (1970). The herbarium of Aylmer Bourke Lambert: Notes on its acquisition, dispersal, and present whereabouts. Taxon 19(4): 489 - 553.

Moore, R. J. (1972). Distribution of native and introduced knapweeds (Centaurea) in Canada and the United States. Rhodora 74(799): 331 - 346.

Quattrocchi, U. (2000). CRC World dictionary of plant names: common names, scientific names, eponyms, synonyms, and etymology. CRC Press, Boca Raton, London, New York, Washington, D.C. Vol. I: A - C.

Rechinger, K. H. (1955). Bornmüller et son oeuvre comme exporateur botanique en Iran. Taxon 4(5): $97-99$.

(1980). Acroptilon. In: K. H. Rechinger (ed.), Flora Iranica. (Flora des Iranischen Hochlandes und der Umrahmenden Gebirge Persien, Afghanistan, teile von West-Pakistan, Nord-Iraq, Azerbaidjan, Turkmenistan.). Compositae III - Cynareae. Vol. 139B: 308 - 311. Akademische Druck- u. Verlangsanstalt, Graz.

Soskov, J. D. (1959). K sistemitike rodov Rhaponticum Adans. i Leuzea DC. Bot. Mater. Gerb. Bot. Inst. Komarova Akad. Nauk S.S.S.R. 19: 396 - 408.

Susanna, A. (2009). Botanical nomenclature: Master or servant? Collect. Bot. (Barcelona) 28: 141 - 143.

\& Garcia-Jacas, N. [2006] (2007). Tribe Cardueae Cass. In: J. W. Kadereit \& C. Jeffrey (vol. eds), K. Kubitzki (ser. ed.), The families and genera of vascular plants. Vol. VIII. Flowering plants: Eudicots: Asterales, pp. 123 - 147. Springer-Verlag, Berlin, Heidelberg, New York.

Sweet, R. (1830). Sweet's Hortus Britannicus: or, a catalogue of plants cultivated in the gardens of Great Britain; arranged in natural orders: with the addition of the Linnean classes and order to which they belong, reference to the books where they are described, their native places of growth, when introduced, time of flowering, duration, $\mathcal{E}$ reference to figures with numerous synonyms ... Ed. 2. James Ridgway, London.

Turland, N. J., Wiersama, J. H., Barrie, F. R., Greuter, W., Hawksworth, D. L., Herendeen, P. S., Knapp, S., Kusber, W.-H., Li, D.-Z., Marhold, K., May, T. W., McNeill, J., Monro, A. M., Prado, J., Price, M. J. \& Smith, G. F. (eds) (2018). International Code of Nomenclature for algae, fungi, and plants (Shenzhen Code) adopted by the Nineteenth
International Botanical Congress, Shenzhen, China, July 2017. Regnum Veg. 159. Koeltz Botanical Books, Glashütten. DOI https://doi.org/10.12705/ Code. 2018

USDA (2015). Field guide for managing Russian knapweed in the Southwest. TP-R3-16-13. USDA, Southwest Region, Albuquerque.

'Vaillant, S.' (1754). Neue Kennzeichen dreyer Classen von Pflanzen mit zusammengesetzeten Blumen, nämlich: der Cynarocephalarum, dere mit Artischockenenhäuptern. Corymbiferarum, die zusammengesetzte, scheibenförmige Blumen tragen. Cichoracearum, weg-wartartiger. In: W. B. A. von Steinwehr, Königliche Akadademie der Wissenschaften in Paris. Anatomische, Chymische und Botanische Adhandlungen. Breslau 5: 143 - 194, 333 377 [- 388 - according to Stafleu \& Cowan in TLII], $545-613.697-750$.

Vetstream (2014). Toxicity: nigropallidal encephalomalacia. Vetstream Ltd. Vetstream.com (web page visited January 2016).

Willdenow, C. L. (1803). Caroli a Linné Species plantarum exhibente plantas rite cognitas ad genera relatas cum differentiis specificis, nominibus trivialibus synonymis selectis, locis natalibus secundum systema sexuale digestas. Editio quarta, post Reichardianum quinta adjectis vegetabilibus hucusque cognitis curante Carolo Ludovico Willdenow ... Vol. 3 (3). G. C. Nauk, Berolini.

Zhu, S. \& Martins, L. (2011). Rhaponticum Vaill. In: Z. Y. Wu, P. H. Raven \& D. Y. Hong (eds), Flora of China, Vol. 20 - 21 (Asteraceae). Science Press (Beijing) \& Missouri Botanical Garden Press, St. Louis.

Zuloaga, F. O. \& Morrone, O. (eds) (1999). Catálogo de las plantas vasculares de la República Argentina II. A - E (Acanthaceae - Euphorbiaceae (Dicotyledonae)). Monogr. Syst. Bot. Missouri Bot. Gard. St. Louis. 74: [I -] - xxii, 1 - 621 [Asteraceae: $98-353]$.

\section{Publisher's Note}

Springer Nature remains neutral with regard to jurisdictional claims in published maps and institutional affiliations. 